\title{
Effects of the fungus Pestalotiopsis maculans \\ (Ascomycota: Amphisphaeriales) on the gametophytic development of the fern Lygodium venustum (Lygodiaceae)
}

\author{
Julieta Bejar ${ }^{1}$, María Luján Luna ${ }^{1,2^{*}}$, Mónica Adriana Murace ${ }^{3}$
}

\& Mario Carlos Nazareno Saparrat ${ }^{4,5,6, *}$

1. Laboratorio de Anatomía Comparada, Propagación y Conservación de Embriofitas "Elías de la Sota", Facultad de Ciencias Naturales y Museo, Universidad Nacional de La Plata, Boulevard 120 y 61, 1900, La Plata, Buenos Aires, Argentina; julieta.bejar93@gmail.com

2. Comisión de Investigaciones Científicas de la Provincia de Buenos Aires, calle 526 entre 10 y 11, 1900, La Plata, Argentina; lujanluna@fcnym.unlp.edu.ar

3. Protección Forestal, Facultad de Ciencias Agrarias y Forestales, Universidad Nacional de La Plata, calle 60 y 119 , 1900, La Plata, Buenos Aires, Argentina; mmurace@gmail.com

4. Instituto de Fisiología Vegetal (INFIVE), Universidad Nacional de La Plata-CCT-La Plata-Consejo Nacional de Investigaciones Científicas y técnicas (CONICET), Diag. 113 y 61, CC 327, 1900, La Plata, Argentina; masaparrat@fcnym.unlp.edu.ar, masaparrat@yahoo.com.ar

5. Instituto de Botánica Spegazzini, Facultad de Ciencias Naturales y Museo, Universidad Nacional de La Plata, 53 \# 477, 1900, La Plata, Argentina.

6. Cátedra de Microbiología Agrícola, Facultad de Ciencias Agrarias y Forestales, Universidad Nacional de La Plata, 60 y 119, 1900, La Plata, Argentina.

* Correspondence

Received 09-I-2019. Corrected 18-VII-2019. Accepted 02-X-2019.

\begin{abstract}
Lygodium Sw. is the only genus of the family Lygodiaceae, with around 25 to 40 species inhabiting mostly tropical regions worldwide. In Argentina two species develop; one of them, L. venustum, grows in the Northeast of the country. Some species of Lygodium are invasive whereas medicinal uses have been reported for some taxa. As part of a project to ascertain on the reproductive biology of native ferns in Argentina, a fungus was found during in vitro spore culture of L. venustum. Dark brown spots and eruptive pustules were also observed in fertile leaves. Thus, emerged as objectives of this work: 1) to retrieve and identify the fungus from the sporophyte and from the spores cultures, 2) to inquire on the impact of the fungus on gametophyte generation, and 3 ) to perform experiments with untreated spores to demonstrate that the fungus is associated to the spores collected from infested sporophytes. Phytopathological techniques were applied in order to isolate the fungus and then to achieve monosporic cultures. The morpho-biometric features of the conidia corresponded with those of Pestalotiopsis maculans (Corda) Nag Raj [= Pestalotiopsis guepinii (Desm.) Steyaert] (Amphisphaeriales, Ascomycota). Re-inoculation of conidia on healthy gametophytes conducted to their necrosis and death. The percentages of spore germination were initially higher in unsterilized cultures, suggesting that disinfection protocol may have affected spore germination. This is the first report of Pestalotiopsis maculans on the sporophytes of Lygodium venustum. The information that emerges from our work could be useful for the biocontrol of other species of Lygodium, considered weeds in other regions of the world.
\end{abstract}

Key words: pathogenic fungus, ferns, gametophyte, leaf spots, Argentina.

Bejar, J., Luna, M. L., Murace, M. A., \& Saparrat, M. C. N. (2019). Effects of the fungus Pestalotiopsis maculans (Ascomycota: Amphisphaeriales) on the gametophytic development of the fern Lygodium venustum (Lygodiaceae). Revista de Biología Tropical, 67(6), 1520-1530. 
Lygodium Sw. is the only genus of the family Lygodiaceae, with around 25 to 40 species inhabiting mostly tropical regions of the world (Smith et al., 2006; Christenhusz, Zhang, \& Schneider, 2011; PPGI, 2016). The genus is characterized by the creeping, slender rhizomes and the leaves with indeterminate growth, climbing, alternately pinnate. The sori are disposed on lobes of the ultimate segments, with sporangia covered by an antrorse indusium-like subtending flange; the spores are trilete, triangular with straight to convex sides in polar view and the ornamentation is verrucate-tuberculate. Gametophytes are green, cordate; $x=29,30$ (Smith et al., 2006; Ramos Giacosa, 2016).

Commonly, Lygodium occurs in open forests and sometimes along the borders of streams or river banks, settling frequently in areas with disturbed vegetation (Tryon \& Tryon, 1982). In Argentina, one of the two species registered is L. venustum Sw., which grows in the Northeast of this country (Ramos Giacosa, 2016). This fern inhabits islets of the Uruguay River (about 140 meters above sea level), along with a shrubby vegetation dominated by Mimosa pigra L. var. pigra (Fabaceae), Chomelia obtusa Cham. \& Schltdl. (Rubiaceae) y Lafoensia nummularifolia A. St.-Hil. (Lythraceae) (Arana, Ramos Giacosa, \& Oggero, 2015).

In literature, some research on Lygodium sp has addressed the gametophyte morphogenesis and reproductive biology, e.g. Raghavan (1973) and Pérez-García, Orozco-Segovia, and Riba (1994) analysed the effects of light on spore germination and gametophyte development in L. japonicum and L. heterodoxum, respectively. Lott, Volin, Pemberton, and Austin (2003) studied the sexual expression in gametophytes of L. japonicum and L. microphyllum, along with sporophyte development, in order to ascertain on their ability to colonize and spread through foreign habitats. For L. venustum, Mendoza, Pérez-García, and Riba (1999) described the prothallial development and suggested the presence of hormonal substances with antheridogenic effects, in association with the production of unisexual male and female gametophytes.

From the economic point of view, some species of Lygodium (e.g. L. japonicum and $L$. microphyllum) are considered invasive plants, since they propagate quickly outside their natural distribution areas displacing native species (Pemberton \& Ferriter, 1998; Brandt \& Black 2001; Lott et al., 2003). Medicinal uses have also been reported for some taxa of Lygodium, as $L$. flexuosum and $L$. venustum (Calzada, Yépez-Mulia, \& Tapia-Contreras, 2007; Nayak, Rath, Mishra, Ghosh, \& Padhy, 2013).

Pestalotiopsis Steyaert is a genus that groups species with appendage-bearing conidia in the Amphisphaeriaceae and is widely distributed throughout tropical and temperate regions (Maharachchikumbura, Guo, Chukeatirote, Bahkali, \& Hyde, 2011). These species are common phytopathogens that cause a variety of diseases, as cankers, shoot dieback or leaf spots in a range of hosts (Crous et al., 2011; Zhang, Maharachchikumbura, Tian, \& Hyde, 2013; Maharachchikumbura, Hyde, Groenewald, $\mathrm{Xu}, \&$ Crous, 2014; Chen et al., 2018). In the last decade, Pestalotiopsis has received considerable attention as a commonly isolated endophyte which produces a wide range of chemically novel diverse metabolites (Maharachchikumbura et al., 2011).

Regarding ferns, few interactions with Pestalotiopsis have been reported, e.g. as endophyte in roots of Equisetum sp. (Sati \& Belwal, 2005), or as pathogen on leaves of Adiantum sp. (Kumaresan, Veeramohan, Bhat, Sruthi, \& Ravindran, 2013), and even as saprobe on decaying leaves of Pteridium sp. (Maharachchikumbura, Guo, Chukeatirote, \& Hyde, 2013).

As part of a project to ascertain on the reproductive biology of native ferns in Argentina (Luna et al., 2016; Ramos Giacosa et al., 2017; Gorrer, Berrueta, Ramos Giacosa, Giudice, \& Luna, 2018), a fungus was found during in vitro spore culture of $L$. venustum. After examining the sporophytes with magnifying glass, dark brown spots and eruptive pustules were observed in fertile leaves. Thus, emerged 
as objectives of this work: 1) to retrieve and identify the fungus from the sporophyte and from the spore cultures, 2) to inquire on the impact of the fungus on gametophyte generation, and 3) to perform experiments with untreated spores to demonstrate that the fungus is associated to the spores collected from infested sporophytes.

\section{MATERIALS AND METHODS}

Plant material: Fertile leaves of $L$. venustum were collected in "Moconá" Provincial Park, Misiones, Argentina $\left(27^{\circ} 08^{\prime} 35^{\prime \prime} \mathrm{S} \&\right.$ 5353'12" W) in February 2017. A voucher specimen was deposited in the LP herbarium of Museo de Ciencias Naturales, Universidad Nacional de La Plata (Marquez, Yañez, \& Ocampo Terraza 469, LP).

Isolation and identification of the fungus: Phytopathological techniques were applied in order to isolate the fungus and then to achieve pure cultures by single spore culture technique (monosporic cultures), employing the culture medium potato dextrose agar (PDA) $2 \%$.

Fungal colonies were obtained from cirri emerging of conidiomata (eruptive pustules) present in the leaves. For this, material was exposed to conditions of high temperature and humidity $\left(25 \pm 2{ }^{\circ} \mathrm{C}\right.$ and $80 \% \mathrm{HR}$, moist chambers). Also, freehand sections with razor blades were obtained from leaf portions with necrotic spots. Specimens were disinfected in alcohol $70 \%$ and sodium hypochlorite $(\mathrm{NaClO}) 1 \%$ (1 minute each), washed three times in distilled water ( 5 min each) and sown in Petri dishes with culture medium. The dishes were incubated at $25 \pm 2{ }^{\circ} \mathrm{C}$. Isolations were also performed from cirri differentiated during non-disinfected spore cultures.

Given the finding of conidia presumably assignable to Pestalotiopsis sp, we followed Sutton (1980) and Maharachchikumbura et al. (2011) to identify the fungus. These authors consider that conidial morphology is the most widely used taxonomic character in this genus.
Thereby, conidia size (length and width), median cells colour, position, length and number of the apical appendages, among others, were taken into account.

For light microscopy, conidia were mounted in distilled water and examined under a microscope Nikon E-200. The isolated strain (LPSC 1407) was deposited in the Spegazzini Institute, Facultad de Ciencias Naturales y Museo, Universidad Nacional de La Plata (LPSC).

In-vitro spore culture and gametophyte development: Leaf portions with mature closed sporangia were put in paper envelopes and stored at ambient temperature (about 24 ${ }^{\circ} \mathrm{C}$ ) to allow spores to be released. Then they were separated from remains of sporangia by filtering through metallic meshes with pores 44-88 $\mu \mathrm{m}$. Spores were sorted in six groups and sown in sterilized petri dishes $(6 \mathrm{~cm}$ in diameter) containing Dyer agar medium (Dyer, 1979). A batch of spores was treated previously with $10 \%(\mathrm{v} / \mathrm{v})$ solution of commercial sodium hypochlorite during $2 \mathrm{~min}$, and then rinsed three times in sterile distilled water (Amoroso \& Amoroso, 1998). The culture medium was also supplemented with $1 \%$ Nystatin (Denver Farma, $100000 \mathrm{U} \mathrm{x} \mathrm{ml}^{-1}$ ) (Simabukuro, Dyer, Felippe, 1998; Ranal, 1999). Another set of spores was sown on the same culture medium without previous disinfection or supplementation of Nystatin. The petri dishes were incubated in a growth chamber under cool white fluorescent illumination of $28 \mu \mathrm{mol} \mathrm{m} \mathrm{m}^{-2} \mathrm{~s}^{-1}$ photosynthetic photon flux, with a photoperiod of $12 \mathrm{~h}$ light and a temperature of $22 \pm 2{ }^{\circ} \mathrm{C}$.

Spore germination and gametophyte development were monitored through periodical observations under a stereoscopic microscope (Nikon SMZ 1000) and a light microscope (Nikon E200). The criterion for germination was the breakage of the exine and protrusion of the rhizoid. The percentages and time of spore germination were calculated by counting the number of germinated ones in five $0.5 \mathrm{x}$ $0.5 \mathrm{~cm}$ fields contained in a marked grid per capsule (Trejo, Pérez-García, Pérez-Salicrup, 
\& Orozco-Segovia, 2010). The percentages of germinated spores (mean $\pm \mathrm{SE}$ ) with or without a disinfection procedure were compared with a paired t-test using the software $R$ (R Core Team, 2009). Normality and homogeneity of variance assumptions were previously tested. The percentage values were transformed to arcsine and then transformed back to percentage for data presentation.

\section{Re-inoculation of the fungus on healthy} gametophytes: A conidial suspension obtained from the pure colonies was previously filtrated through several layers of cheesecloth, and then applied to 20 days-old filamentous gametophytes obtained in axenic conditions. The subsequent development of these gametophytes was monitored to evaluate the appearance of any symptom.

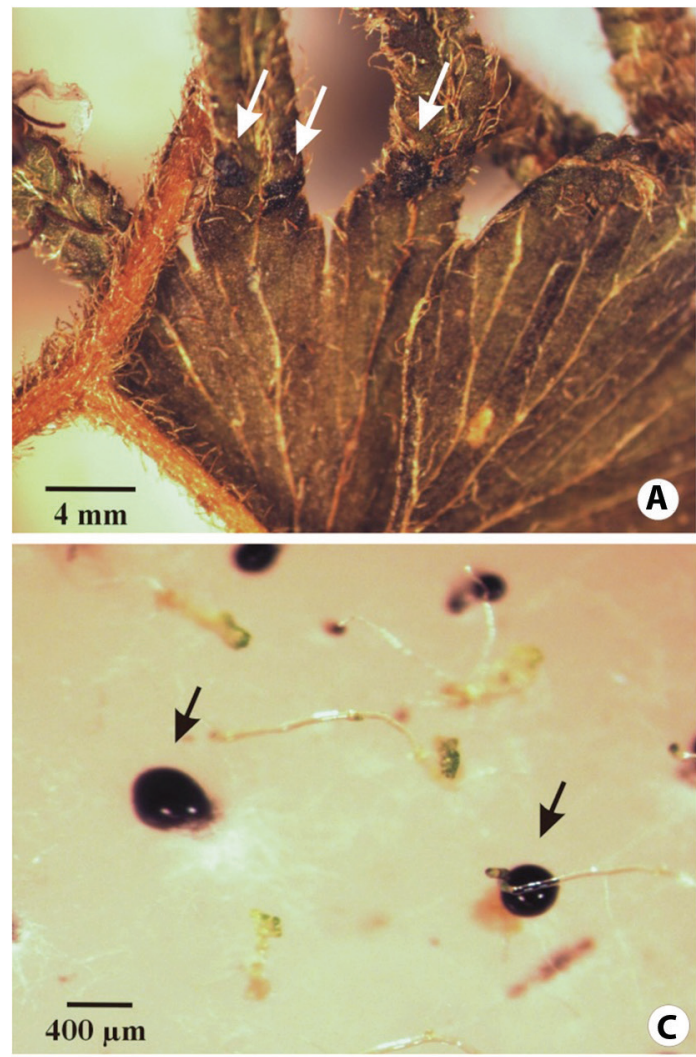

\section{RESULTS}

Identification of the fungus: The morpho-biometric features of the conidia isolated from the sporophyte of $L$. venustum (Fig. 1A, Fig. 1B) and the cirri developed during spore cultures (Fig. 1C) corresponded with those of Pestalotiopsis maculans (Corda) Nag Raj [= Pestalotiopsis guepinii (Desm.) Steyaert] (Amphisphaeriales, Ascomycota) (Sutton, 1980; Maharachchikumbura et al., 2014; Judith-Hertz, 2016). Conidia 5-celled, straight or sometimes slightly curved, ellipsoidal or fusiform, sometimes strongly constricted at the first apical septum (the septum of the second apical cell often thicker), 18.5-27 × 4.6-6.9 $\mu \mathrm{m}(\mathrm{n}=30)$; the three middle cells doliiform, concolorous (predominant), thick-walled, 13.8$18.4 \mu \mathrm{m}$ long $(\mathrm{n}=30)$; exterior cells smooth,
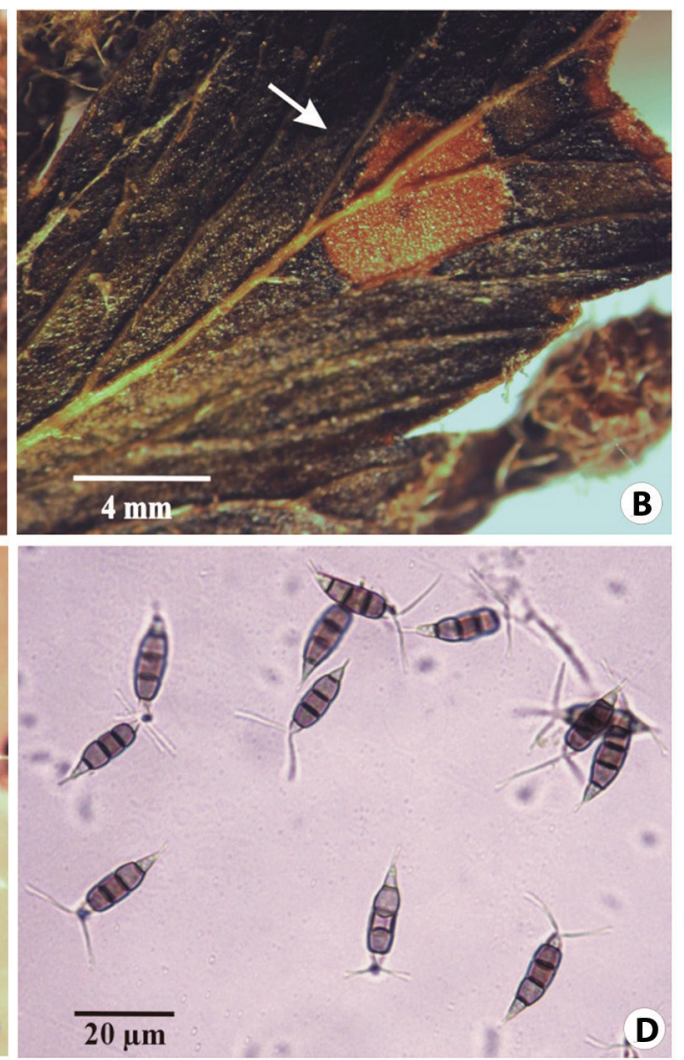

Fig. 1. Evidences of Pestalotiopsis maculans in sporophyte and spore cultures of Lygodium venustum. (A) Leaf with dark pustules (conidiomata) (arrows) close to the fertile leaf portion. (B) Necrotic spot on the leaf (arrow). (C) Cirri differentiated in non-disinfected spore cultures (arrows). (D) Conidia of P. maculans. 


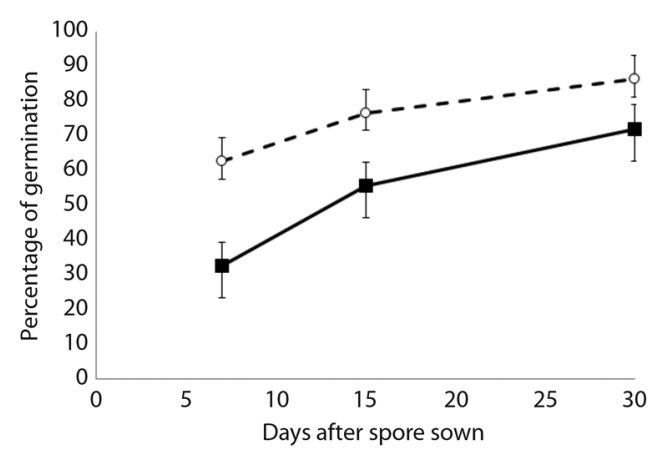

Fig. 2. Mean percentages ( $\pm \mathrm{SE}$ ) of Lygodium venustum spores germinated with previous disinfection treatment (solid line) and without disinfection (dotted line) measured during 30 days after sowing.

thin-walled, hyaline to subhyaline, apical cell conic, bearing appendages variable in number and size, mostly 3, unbranched, 3.8-16.1 $\mu \mathrm{m}$ long. $(\mathrm{n}=30)$; basal cell broadly conic with a somewhat truncate base, possessing one single, centric appendage, unbranched, up to $5 \mu \mathrm{m}$ long $(\mathrm{n}=30)$ (Fig. 1D).

Spore germination and gametophyte development: All spores began to germinate at seven days after sowing, and those unsterilized did it at significant higher percentage $(\mathrm{t}=5.02$; $\mathrm{df}=10, \mathrm{P}=0.0005$ ) (Fig. 2, Fig. 3A). At 15 days from sowing, germination reached ca. 76.5 $\%$ and $55.7 \%$ in non-disinfected and disinfected cultures respectively, and percentages of germination differed between treatments $(\mathrm{t}=5.47$; $\mathrm{df}$ $=10, \mathrm{P}=0.0002$ ). Same pattern was observed for 30 days after sowing, since germination showed significant different percentages (86.3 $\%$ for unsterilized and $72 \%$ for sterilized cultures; $\mathrm{t}=3.16$; $\mathrm{df}=10, \mathrm{P}=0.01$ ). The spores did not longer germinate in any treatment after 30 days of starting the experiment.

Filamentous gametophytes were observed at 12-15 days from sowing (Fig. 3B) and spatulate ones about five days later (Fig. 3C). In non-disinfected cultures, long filamentous and spatulate gametophytes developed in close association to mycelial masses with black and mucilaginous exudates (the fungus was presumably carried by the spores) (Fig. 3D).
The first evidences of necrosis were observed in early stages of their development (Fig. 3E, Fig. 3F). At 60 days from spore sown, they remained in the filamentous and spatulate stages (near $70 \%$ in the latter) and showed an advanced necrosis.

In disinfected cultures, the gametophytes acquired the cordiform shape approximately at 40 days from sowing, and about 10-15 days later they developed antheridia and archegonia (Fig. 4A, Fig. 4B). In the same capsules, some gametophytes remained spatulate and produced only antheridia (Fig. 4C).

Re-inoculation of $P$. maculans conidia on developing gametophytes: Within 3-5 days of inoculation the first evidences of necrosis were observable in gametophytes (mean 55.2 $\%$; SEM $5.7 \%$ ) (Fig. 4D, Fig. 4E). After 10 days from fungal inoculation, most of the gametophytes became necrotic (mean $79.8 \%$; SEM $16.4 \%$ ) and 20 days later all of them died (Fig. 4F).

\section{DISCUSSION}

There is scarce information on fungi causing disease in natural populations of Lygodium spp., i.e. Puccinia lygodii (Har.) Arth. (Uredinales) on sporophytes of $L$. volubile and L. venustum in South America (Cardona, 1998; Carvalho Júnior, Figueiredo, Furtado, \& Hennen, 2007), as well as on L. japonicum in Florida, USA (Hennen \& McCain, 1993; Rayachhetry, Pemberton, Smith, \& Leahy, 2001), or Bipolaris sacchari (E. Butler) Shoem. (Pleosporales) on L. japonicum in Florida, USA (Elliot \& Rayamajhi, 2005).

To our knowledge, this is the first report of Pestalotiopsis maculans on sporophytes of Lygodium venustum, associated to dark brown spots on leaves. This fungus was also found in leaves of Adiantum sp. and Pteridium aquilinum in other regions of the world (Kumaresan et al., 2013; Maharachchikumbura et al., 2013). Although necrotic spots were observed in the leaves of L. venustum, and isolations of $P$. maculans were obtained from them, 


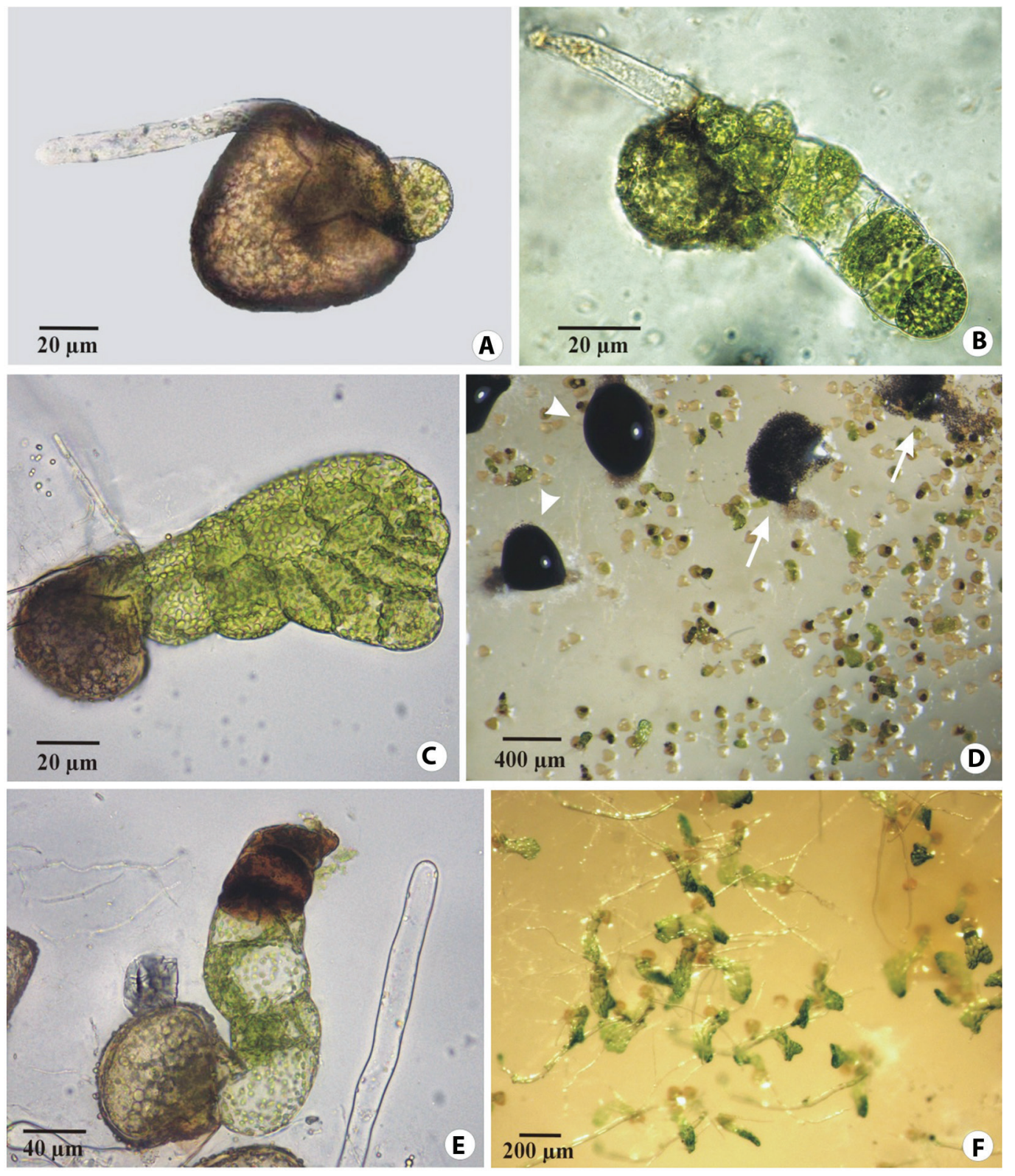

Fig. 3. Development of Lygodium venustum gametophytes in unsterilized spore cultures. (A) Germinated spore showing the hyaline rhizoid and the protonemal initial. (B) Early filamentous phase of the gametophyte. (C) Spatulate gametophyte. (D) Cirri differentiation (arrowheads) and release of conidia (arrows) among the gametophytes. (E) About 7 days-old gametophytes with signs of necrosis. (F) Long filamentous and spatulate gametophytes growing among fungal hyphae. 

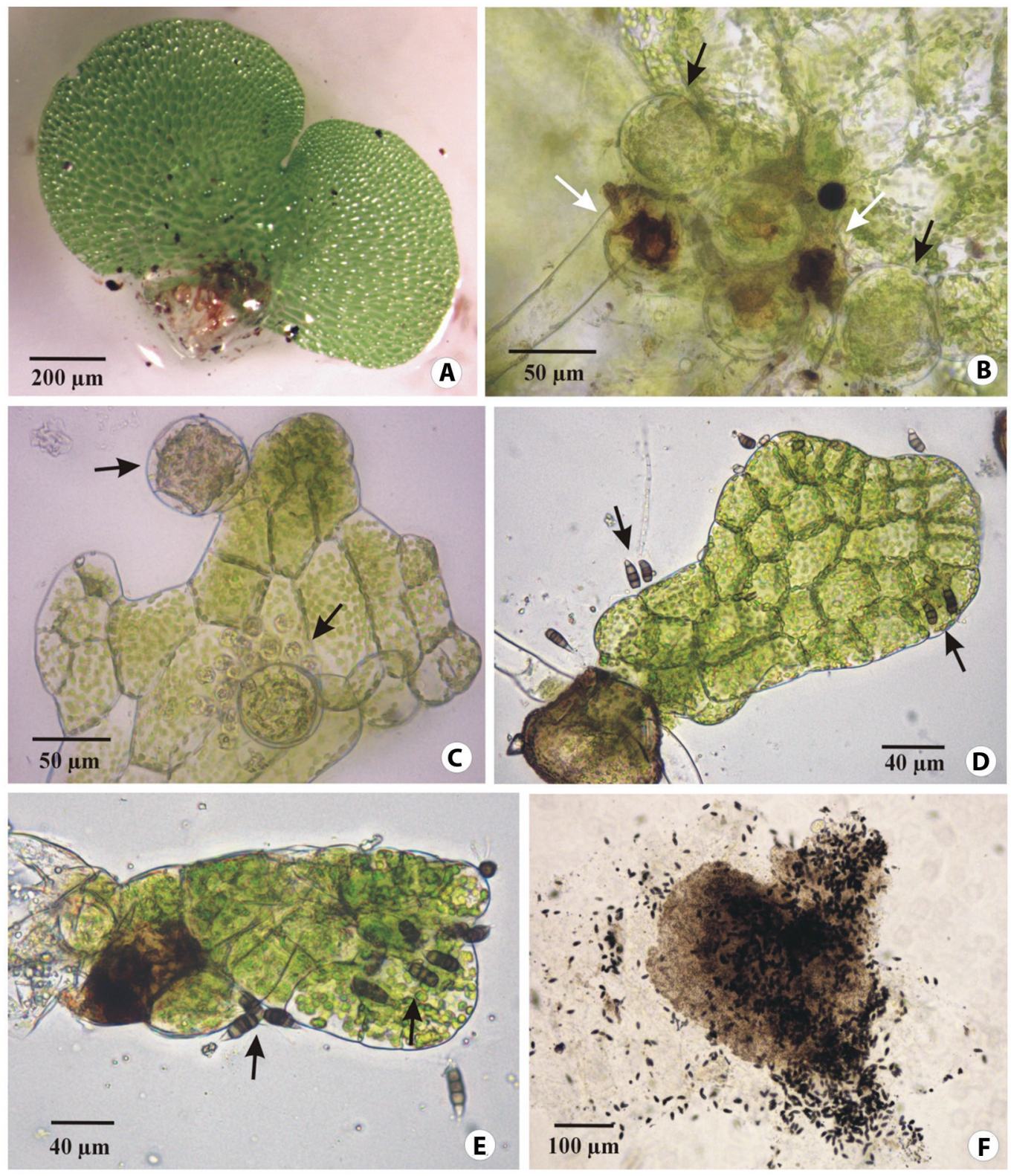

Fig. 4. Development of Lygodium venustum gametophytes in sterilized and reinoculated cultures. (A-C) Gametophytes developed in disinfected cultures. (A) Cordiform bisexual gametophyte. (B) Detail of antheridia (black arrows) and archegonia (white arrows). (C) Spatulate male gametophyte (arrows points to antheridia). (D-F) Gametophytes from reinoculated cultures. (D) Spatulate healthy gametophyte with conidia of P. maculans on its surface (arrows). (E) First symptoms of gametophyte necrosis associated with the presence of conidia (arrows). (F) Completely necrotic gametophyte covered by a lot of conidia. 
further studies are necessary to demonstrate its pathogenicity on the sporophyte applying the Koch's postulates (i.e. the critical steps to prove that a particular agent is the cause of a specific disease in a host organism; Agrios, 2005). The pathogenicity of $P$. maculans on the gametophytes of $L$. venustum is verified in the present work.

Fungi may also inhibit prothallial development in cultures (Hutchinson, 1976). In our assays, about $30 \%$ of the gametophytes growing in contaminated cultures remained filamentous whereas the remaining reached the spatulate stage. Smith and Robinson (1969) also observed that the addition of a fungus in spore cultures of Polypodium vulgare delayed the transition from one to two-dimensional growth of the gametophytes.

Under our laboratory conditions both, bisexual and unisexual male gametophytes developed. Mendoza et al. (1999) obtained only unisexual (male or female) gametophytes of $L$. venustum, employing material from Mexico and Thompson's nutritive medium. Differences might be related to the genetic source of the plant as well as the incubation conditions and/ or the nutritional components of the medium, which could activate specific physiological processes leading to a reproductive variation (Suo, Chen, Zhao, Shi, \& Dai, 2015). In our cultures, the development of male gametophytes along with bisexual ones suggests the presence of some antheridiogen (Yamauchi et al., 1996; Yamane, 1998). This substance would be produced by bisexual gametophytes, inducing the production of antheridia on neighbouring smaller or slower-growing ones (Willson, 1981; Seral, Flores-Bavestrello, \& Gabriel y Galan, 2016).

The sterilization treatment may have affected spore germination (the significant higher percentages were obtained in non-disinfected cultures), as has been reported previously by other authors. Simabukuro et al. (1998) found that pre-treatment of spores of Cyathea delgadii with sodium hypochlorite in concentrations above $0.5 \%$ reduced fungal and bacterial contamination, but also reduced spore germination. Camloh (1999) also observed better percentages of germination by sowing unsterilized spores of Platycerium bifurcatum. According to this author, changes might occur in spores during the sterilization procedure (e.g. $\mathrm{Ca}^{2+}$ removal) that affects spore germination. Thus, disinfection protocols using concentrations of less than $10 \%$ of sodium hypochlorite are recommended if it would be necessary propagate $L$. venustum in laboratory.

The information that emerges from our investigations, on the interaction Pestalotiopsis maculans - Lygodium venustum, could be useful for the biocontrol of other species of Lygodium, considered weeds in other regions of the world.

Ethical statement: authors declare that they all agree with this publication and made significant contributions; that there is no conflict of interest of any kind; and that we followed all pertinent ethical and legal procedures and requirements. All financial sources are fully and clearly stated in the acknowledgements section. A signed document has been filed in the journal archives.

Julieta Bejar and María Luján Luna: Both authors contributed equally to this work.

\section{ACKNOWLEDGMENTS}

To Gabriela Luna for her contributions during the processing of the results. To the reviewers and editors, who contributed to improve the manuscript. To Universidad Nacional de La Plata for financing the Fern Conservation Project in Argentina N 850 (María Luján Luna). This research was also supported by the Agencia Nacional de Promoción Científica y Tecnológica (ANPCyT) of the Ministerio de Ciencia, Tecnología e Innovación Productiva through the project PICT 2015-1620 (Mario Carlos Nazareno Saparrat), CONICET (PUE INFIVE), CICPBA and UNLP, Argentina. 
Saparrat, M. C. N. is a researcher from the CONICET, Argentina.

\section{RESUMEN}

Efectos del hongo Pestalotiopsis maculans (Ascomycota: Amphisphaeriales) en el desarrollo gametofítico del helecho Lygodium venustum (Lygodiaceae). Lygodium Sw. es el único género de la familia Lygodiaceae, con alrededor de 25 a 40 especies que habitan en su mayoría en regiones tropicales del mundo. En Argentina se desarrollan dos especies; uno de ellas, L. venustum, crece en el noreste del país. Algunas especies de Lygodium son invasivas, mientras que para algunos taxones se han reportado usos medicinales. Como parte de un proyecto para indagar sobre la biología reproductiva de los helechos nativos en Argentina, se encontró un hongo durante el cultivo in vitro de esporas de L. venustum. Asimismo, se observaron manchas marrones oscuras y pústulas eruptivas en hojas fértiles. Así, surgieron como objetivos de este trabajo: 1) recuperar e identificar el hongo presente en el esporofito y en los cultivos de esporas, 2) investigar el impacto del hongo en la generación gametofítica y 3) realizar experimentos con esporas no tratadas para demostrar que el hongo está asociado a las esporas recolectadas de esporofitos infestados. Se aplicaron técnicas fitopatológicas para aislar el hongo y luego lograr cultivos monospóricos. Las características morfo-biométricas de los conidios correspondieron a las de Pestalotiopsis maculans (Corda) Nag Raj [= Pestalotiopsis guepinii (Desm.) Steyaert] (Amphisphaeriales, Ascomycota). La re-inoculación de conidios en gametofitos sanos condujo a su necrosis y muerte. Los porcentajes de germinación de esporas fueron inicialmente más altos en los cultivos no esterilizados, lo que sugiere que el protocolo de desinfección pudo haber afectado la germinación de las esporas. Este es el primer reporte de Pestalotiopsis maculans sobre los esporofitos de Lygodium venustum. La información que surge de nuestro trabajo podría ser útil para el control biológico de otras especies de Lygodium, consideradas malezas en otras regiones del mundo.

Palabras clave: hongo patógeno, helechos, gametofito, manchas foliares, Argentina.

\section{REFERENCES}

Agrios, G. N. (2005). Plant Pathology (5 ${ }^{\text {th }}$ ed.). San Diego, California: Academic Press.

Amoroso, C. B., \& Amoroso, V. B. (1998). Spore culture studies on some economic ferns of Mindanao, Philippines. Acta Horticulturae, 461, 231-236.

Arana, M. D., Ramos Giacosa, J. P., \& Oggero, A. (2015). Revalidación de la presencia de Lygodium venustum
(Lygodiaceae) en la Argentina, con notas nomenclaturales. Darwiniana, 3(2), 227-234.

Brandt, L. A., \& Black, D. W. (2001). Impacts of the introduced fern, Lygodium microphyllum, on the native vegetation of tree islands in the Arthur R. Marshall Loxahatchee National Wildlife Refuge. Florida Scientist, 64, 191-196.

Calzada, F., Yépez-Mulia, L., \& Tapia-Contreras, A. (2007). Effect of Mexican medicinal plant used to treat trichomoniasis on Trichomonas vaginalis trophozoites. Journal of Ethnopharmacology, 113, 248-251.

Camloh, M. (1999). Spore age and sterilization affects germination and early gametophyte development of Platycerium bifurcatum. American Fern Journal, 89(2), 124-132.

Cardona, V. M. P. (1998). Distribución de las especies colombianas de Uredinales según los grupos taxonómicos de sus hospederos. Revista Facultad Nacional de Agronomía Medellín, 51(2), 285-319.

Carvalho Júnior, A. A. D., Figueiredo, M. B., Furtado, E. L., \& Hennen, J. F. (2007). Uredinales sobre Blechnaceae, Thelypteridaceae, Schizaeaceae, Myrtaceae, Oxalidaceae, Rhamnaceae, Rubiaceae, Sapindaceae, Smilacaceae e Vitaceae da Reserva Florestal "Armando de Salles Oliveira", São Paulo, SP, Brasil. Hoehnea, 34(4), 481-492.

Chen, Y., Zeng, L., Shu, N., Jiang, M., Wang, H., Huang, Y., \& Tong, H. (2018). Pestalotiopsis-like species causing gray blight disease on Camellia sinensis in China. Plant disease, 102(1), 98-106.

Christenhusz, M. J. M., Zhang, X., \& Schneider, H. (2011). A linear sequence of extant families and genera of lycophytes and ferns. Phytotaxa, 19, 7-54.

Crous, P. W., Summerell, B. A., Swart, L., Denman, S., Taylor, J. E., Bezuidenhout, C. M., Groenewald, J. Z. (2011). Fungal pathogens of Proteaceae. Persoonia: Molecular Phylogeny and Evolution of Fungi, 27, 20.

Dyer, A. F. (1979). The culture of fern gametophytes for experimental investigation. In A. F. Dyer (Ed.), The experimental biology of ferns (pp. 253-305). London: Academic Press.

Elliott, M. L., \& Rayamajhi, M. B. (2005). First report of Bipolaris sacchari causing leaf spot on Lygodium japonicum and L. microphyllum in Florida. Plant Disease, 89, 1244.

Gorrer, D. A., Berrueta, P. C., Ramos Giacosa, J. P., Giudice, G. E., \& Luna, M. L. (2018). Morphogenesis of the sexual phase of the epiphytic ferns Microgramma mortoniana and Pleopeltis macrocarpa (Polypodiaceae) from Punta Lara Natural Reserve, Buenos Aires, Argentina. Revista de Biología Tropical, 66(3), 1078-1089. 
Hennen, J. F., \& McCain. J. W. (1993). New species and records of Uredinales from the Neotropics. Mycologia, 85(6), 970-986.

Hutchinson, S. A. (1976). The effects of fungi on bracken. Botanical Journal of the Linnean Society, 73(1-3), 145-150.

Judith-Hertz, C. (2016). Systematics and species delimitation in Pestalotia and Pestalotiopsis s.l. (Amphisphaeriales, Ascomycota) (Doctorate Thesis). Frankfurt, Germany: Goethe-Universität Frankfurt am Main.

Kumaresan, V., Veeramohan, R., Bhat, M. M., Sruthi, K., \& Ravindran, C. P. (2013). Fungal endophyte assemblages of some Pteridophytes from Mahe, India. World Journal of Science and Technology, 3(1), 7-10.

Lott, M. S., Volin, J. C., Pemberton, R. W., \& Austin, D. F. (2003). The reproductive biology of the invasive ferns Lygodium microphyllum and L. japonicum (Schizaeaceae): implications for invasive potential. American Journal of Botany, 90(8), 1144-1152.

Luna, M. L., Yáñez, A., Ramos Giacosa, J. P., Gorrer, D., Berrueta, P. C., \& Giudice, G. E. (2016). In vitro culture of the annual fern Anogramma chaerophylla (Pteridaceae): strategy for its conservation in Buenos Aires Province, Argentina. Boletín de la Sociedad Argentina de Botánica, 51(4), 675-682.

Maharachchikumbura, S. S. N., Guo, L. D., Chukeatirote, E., Bahkali, A. H., \& Hyde, K. D. (2011). Pestalotiopsis-morphology, phylogeny, biochemistry and diversity. Fungal Diversity, 50, 167-187.

Maharachchikumbura, S. S. N., Guo, L. D., Chukeatirote, E., \& Hyde, K. D. (2013). Improving the backbone tree for the genus Pestalotiopsis; addition of P. steyaertii and P. magna sp. nov. Mycological Progress, 13(3), 617-624.

Maharachchikumbura, S. S., Hyde, K. D., Groenewald, J. Z., Xu, J., \& Crous, P. W. (2014). Pestalotiopsis Studies in Mycology, 79, 121-186.

Mendoza, A., Pérez-García, B., \& Riba, R. (1999). Desarrollo protálico de Lygodium heterodoxum y Lygodium venustum (Schizaeaceae). Revista de Biología Tropical, 47(1-2), 83-92.

Nayak, N., Rath, S., Mishra, M. P., Ghosh, G., \& Padhy, R. N. (2013). Antibacterial activity of the terrestrial fern Lygodium flexuosum (L.) Sw. against multidrug resistant enteric- and uro-pathogenic bacteria. Journal of Acute Disease, 2, 270-276.

Pemberton, R. W., \& Ferriter, A. P. (1998). Old World Climbing Fern (Lygodium microphyllum), dangerous invasive weed in Florida. American Fern Journal, 88(4), 165-175.

Pérez-García, B., Orozco-Segovia, A., \& Riba, R. (1994). The effects of white fluorescent light, far-red light, darkness, and moisture on spore germination of Lygodium heterodoxum (Schizaeaceae). American Journal of Botany, 81(11), 1367-1369.

PPG I. (2016). A community-derived classification for extant lycopods and ferns. Journal of Systematics and Evolution, 54(6), 563-603.

Raghavan, V. (1973). Photomorphogenesis of the gametophytes of Lygodium japonicum. American Journal of Botany, 60(4), 313-321.

Ramos Giacosa, J. P. (2016). Lygodiaceae. In A. Anton, F. Zuloaga \& M. Belgrano (Eds.), Flora Vascular de la República Argentina 2: Licofitas, Helechos y Gimnospermae (pp. 207-208). Buenos Aires: Estudio Sigma SRL.

Ramos Giacosa, J. P., Gorrer, D. A., Giudice, G. E., \& Luna, M. L. (2017). Gametophyte development and conservation of Ctenitis submarginalis (Dryopteridaceae) in Buenos Aires Province, Argentina. Boletín de la Sociedad Argentina de Botánica, 52(4), 697-703.

Ranal, M. A. (1999). Effects of temperature on spore germination in some fern species from semideciduous mesophytic forest. American Fern Journal, 89, 149-158.

Rayachhetry, M. B., Pemberton, R. W., Smith, L. L., \& Leahy, R. (2001). Pathogenicity assessment of Puccinia lygodii, a potential biological control agent of Lygodium japonicum in southeastern United States. Plant Disease, 85(2), 232.

R Core Team (2009). R: a language and environment for statistical computing. Vienna, Austria: R Foundation for Statistical Computing.

Sati, S. C., \& Belwal, M. (2005). Aquatic hyphomycetes as endophytes of riparian plant roots. Mycologia, 97(1), 45-49.

Seral, A., Flores-Bavestrello, A., \& Gabriel y Galan, J. M. (2016). Gametophyte development and reproduction of two Chilean fern species, Blechnum arcuatum (Blechnaceae) and Pteris semiadnata (Pteridaceae). Gayana Botanica, 73(2), 346-354.

Simabukuro, E. A., Dyer, A. F., \& Felippe, G. M. (1998). The effect of sterilization and storage conditions on the viability of the spores of Cyathea delgadii. American Fern Journal, 88, 72-80.

Smith, A. R., Pryer, K. M., Schuettpelz, E., Korall, P., Schneider, H., \& Wolf, P. G. (2006). A classification for extant ferns. Taxon, 55(3), 705-731.

Smith, D. L., \& Robinson, P. M. (1969). The effects of fungi on morphogenesis of gametophytes of Polypodium vulgare L. New Phytologist, 68(1), 113-122. 
Suo, J., Chen, S., Zhao, Q., Shi, L., \& Dai, S. (2015). Fern spore germination in response to environmental factors. Frontiers in Biology, 10(4), 358-376.

Sutton, B. C. (1980). The Coelomycetes: Fungi imperfecti with pycnidia, acervuli, and stromata. Kew, UK: Commonwealth Mycological Institute.

Trejo, M. D. R. R., Pérez-García, B., Pérez-Salicrup, D. R., \& Orozco-Segovia, A. (2010). Effect of fire on the germination of spores of Pteridium caudatum, an invasive fern. Journal of Tropical Ecology, 26(4), 457-465.

Tryon, R. M., \& Tryon, A. F. (1982). Ferns and allied plants with special reference to tropical America. Cambridge, MA: Springer Verlag.
Willson, M. F. (1981). Sex expression in fern gametophytes: some evolutionary possibilities. Journal of Theoretical Biology, 93, 403-409.

Yamane, H. (1998). Fern antheridiogens. International Review of Cytology, 184, 1-32.

Yamauchi, T., Oyami, N., Yamane, H., Murofushi, N., Schraudolf, H., Pour, M., Mander, L. (1996). Identification of antheridiogens in Lygodium circinnatum and Lygodium flexuosom. Plant Physiology, 111, 741-745.

Zhang, Y. M., Maharachchikumbura, S. S. N., Tian, Q., \& Hyde, K. D. (2013). Pestalotiopsis species on ornamental plants in Yunnan Province, China. Sydowia, $65,59-74$. 